\title{
IAMJ
}

INTERNATIONAL

AYURVEDIC

MEDICAL JOURNAL

(क) $\partial 0$

Case Report

ISSN: 2320-5091

Impact Factor: 6.719

\section{EFFECT OF POLYHERBAL FORMULATION IN SHEETAPITTA (URTICARIA): A CASE STUDY}

\author{
Verma Neeharika ${ }^{1}$, Verma Keerti ${ }^{2}$ \\ ${ }^{1}$ M.D. Scholar $3^{\text {rd }}$ Year, Department of Kaumarbhritya, Rishikul Campus, UAU, Haridwar, Uttarakhand, India \\ ${ }^{2}$ Prof. \& H.O.D in Department of Kaumarbhritya, Rishikul Campus, UAU, Haridwar, Uttarakhand, India
}

Corresponding Author: neeharikaverma1995@gmail.com

\section{https://doi.org/10.46607/iamj4109122021}

(Published Online: December 2021)

Open Access

(C) International Ayurvedic Medical Journal, India

Article Received: 15/11//2021 - Peer Reviewed: 07/12/2021 - Accepted for Publication 08/12/2021

\section{Check for updates}

\begin{abstract}
Aim: Urticaria is a common condition in children for which Paediatricians are consulted. In Ayurveda, it can be correlated with Sheetapitta which is a Tridoshaja vyadhi. The present study is aimed to show the effect of Polyherbal formulation in Sheetapitta (Urticaria) in children. Background: Urticaria is defined as a transient eruption of circumscribed oedematous and usually itchy swellings of the dermis. As per Ayurveda, Urticaria can be correlated with Sheetapitta in terms of clinic features, causative factors and pathogenesis. Case Description: A 14-year-old female patient with her mother from Haridwar district came in OPD of Department of Kaumarbhritya, Rishikul Campus, Uttarakhand Ayurved University, Haridwar with the presenting complaints of red rashes all over the body along with itching, burning sensation and swelling since 2 years also having associated complaints like nasal congestion, sneezing and swelling B/L eyes from 2 months. On examining upper respiratory tract left-sided nasal hypertrophy, chapped lips, white-coated tongue, rt. sided slightly enlarged tonsils were found. On examining the Integumentary system, maculopapular lesions were present mainly over the upper limb, lower limb, chest and back. Swelling underneath B/L eyes was also present. The effect of the treatment was assessed on the basis of relief in itching and clearance of lesions. Conclusion: After the intervention of the polyherbal formulation for 45 days, there was a marked improvement in symptoms like Kandu, Vidaha and Shotha etc. So, it was concluded that internal use of Polyherbal formulation along with external use of Anu taila and the local application of Urtiplex lotion is highly effective in the management of Sheetapitta (Urticaria).
\end{abstract}

Keywords: Urticaria, Sheetapitta, Kandu, Allergic disease 


\section{INTRODUCTION}

The term urticaria is defined as a transient eruption of circumscribed oedematous and usually itchy swellings of the dermis. ${ }^{[1]}$ It is a type I hypersensitivity reaction that is manifested because of allergens. Urticaria is also known as hives, wheels, or nettle rash. ${ }^{[2]}$ It is the fourth most prevalent allergic disease which affects $20 \%$ of the total population once in their life. ${ }^{[3]}$ It can be acute or chronic. Episodes of hives that last for $<6$ weeks are considered acute, whereas those that occur on most days of the week for $>6$ weeks are designated chronic. ${ }^{[4]}$ Acute urticaria is more common in the young population. It is often caused by an allergic $\operatorname{IgE}$ -mediated reaction. It occurs when an allergen activates mast cells in the skin. Common causes are foods, drugs (particularly antibiotics), and stinging-insect venom. Acute urticaria can also result from non-IgEmediated stimulation of mast cells, caused by radiocontrast agents, viral agents (including hepatitis B), opiates, and nonsteroidal anti-inflammatory drugs (NSAIDs). The diagnosis of chronic urticaria is established when lesions occur for more than six weeks and are not physical urticaria or recurrent acute urticaria with repeated exposures to a specific agent. ${ }^{[5]}$ In Ayurveda, allergic diseases are described under the concept of Satmya-Asatmya. Various forms of urticaria can be taken as Sheetapitta. According to Ayurveda, Sheetapitta manifests due to exposure to Asatmya ahara-vihara and contact with different toxic substances (allergens). Vata and Kapha doshas are primarily disturbed in Sheetapitta. Vata Dosha prakopa results in vitiation of Pitta Dosha which leads to the manifestation of symptoms like redness, swelling etc. MATERIALS AND METHODS

Place of study: OPD Department of Kaumarbhritya, Rishikul Campus, Uttarakhand Ayurved University, Haridwar

\section{CASE REPORT:}

A 14-year-old female patient XYZ from Haridwar district with Registration no. B-4606/47732 came with her mother to OPD no. 10 of Kaumarbhritya Department, Rishikul Campus, UAU, Haridwar, with the following complaints:

\section{C/O:}

a. Red rashes all over the body with itching, burning sensation and swelling.

b. Excessive sneezing after taking bath or exposure to AC.

c. Swelling B/L eyes (on/off)

\section{HISTORY OF PRESENT ILLNESS}

According to the patient's mother, the patient was asymptomatic 2 years back. Then suddenly she developed red rashes all over the body along with severe itching, burning sensation and swelling which reoccurs after every 15-20 days. Later on, the patient felt allergic to climate change or cold environment such as being exposed to A.C. or after having a bath with cold water she developed excessive sneezing. Now from the last two months patient had developed the same problem again along with complaints of swelling over $\mathrm{B} / \mathrm{L}$ eyes (on/off). They had consulted their local allopathic doctor for the above complaints and had treatment for 15 months approx. also got some relief for some months but again the symptoms reoccur. Then they came to the Rishikul campus, UAU, Haridwar for further treatment.

\section{HISTORY OF PAST ILLNESS}

Not significant

\section{FAMILY HISTORY}

The patient's family members (Mother, Father, Sister, Brother) do not have any kind of same complaints.

\section{HISTORY OF ALLERGIES}

Excessive sneezing after taking bath with cold water, exposure to AC or during weather change.

\section{IMMUNIZATION HISTORY}

Immunization is appropriate for age. 


\section{PERSONAL HISTORY}

\begin{tabular}{|l|l|l|}
\hline Name: XYZ & Age: 14 years & Sex: Female \\
\hline Habitat: Rural & SES: Middle & Occupation: Student \\
\hline Dietary habit: Vegetarian & Appetite: Average & Bowel: Regular \\
\hline Micturition: Regular & Sleep: Disturbed & Thirst: Normal \\
\hline
\end{tabular}

\section{GENERAL EXAMINATION}

\begin{tabular}{|l|l|l|}
\hline Height: $153 \mathrm{~cm}$ & Lymph nodes: not enlarged & Neck: Trachea centrally placed, normal neck holding \\
\hline Weight: $43 \mathrm{~kg}$ & Tongue: white coated & Cyanosis: Not present \\
\hline Pallor: present & Throat: Rt. Sided tonsil slightly enlarged & Clubbing: Not present \\
\hline Icterus: Not present & Oedema: Peri-orbital oedema & Skin: Red rashes with swelling \\
\hline
\end{tabular}

\section{VITAL SIGNS}

\begin{tabular}{|l|l|}
\hline Heart rate & $80 / \mathrm{min}$ \\
\hline Respiratory rate & $20 / \mathrm{min}$ \\
\hline Blood pressure & $110 / 65 \mathrm{mmHg}$ \\
\hline Temperature & $98.2^{\circ} \mathrm{F}$ \\
\hline
\end{tabular}

\section{SYSTEMIC EXAMINATION}

\section{Respiratory System:}

(a) Inspection:

- URT: Lt. Sided nasal hypertrophy, chapped lips, Tongue white-coated, Rt. Sided tonsil slightly enlarged

- LRT: Chest B/L symmetrical, not any scar mark present

(b) Palpation: Normal B/L thoracic movement, not any tenderness present (c) Percussion: Resonant sound

(d) Auscultation: Chest sound clear

\section{Integumentary System:}

- Reddish lesion over the upper limb, lower limb, chest and back, lesions were maculopapular in nature and had an irregular margin with no discharge.

- The perception of sensation was intact.

- Folds underneath $\mathrm{B} / \mathrm{L}$ eyes.

\section{DASHVIDHA PARIKSHA}

\begin{tabular}{|l|l|}
\hline Prakruti: Vata-Kaphaja & Vikriti: Vata Pradhana Tridoshaja \\
\hline Sara: Mamsasara, Asthisara & Samhanana: Madhyama \\
\hline Pramana: Sama & Satmya: Madhura-Lavana rasa \\
\hline Satva: Madhyama & Ahara Shakti: Madhyama \\
\hline Vyayama Shakti: Madhyama & Vaya: Balyawastha \\
\hline
\end{tabular}

\section{ASHTAVIDHA PARIKSHA}

Nadi: Pittaja

Mutra: Samanya Pravritti

Shabda: Samanya

Druka: Samanya
Mala: Nirama

Jihva: Malavrutta

Sparsha: Ruksha, Ushna

Akriti: Samanya

\section{TREATMENT PLAN}

Patient was treated on OPD level.

Details of Polyherbal formulation (Anubhuta Yoga) which was selected for internal use: 


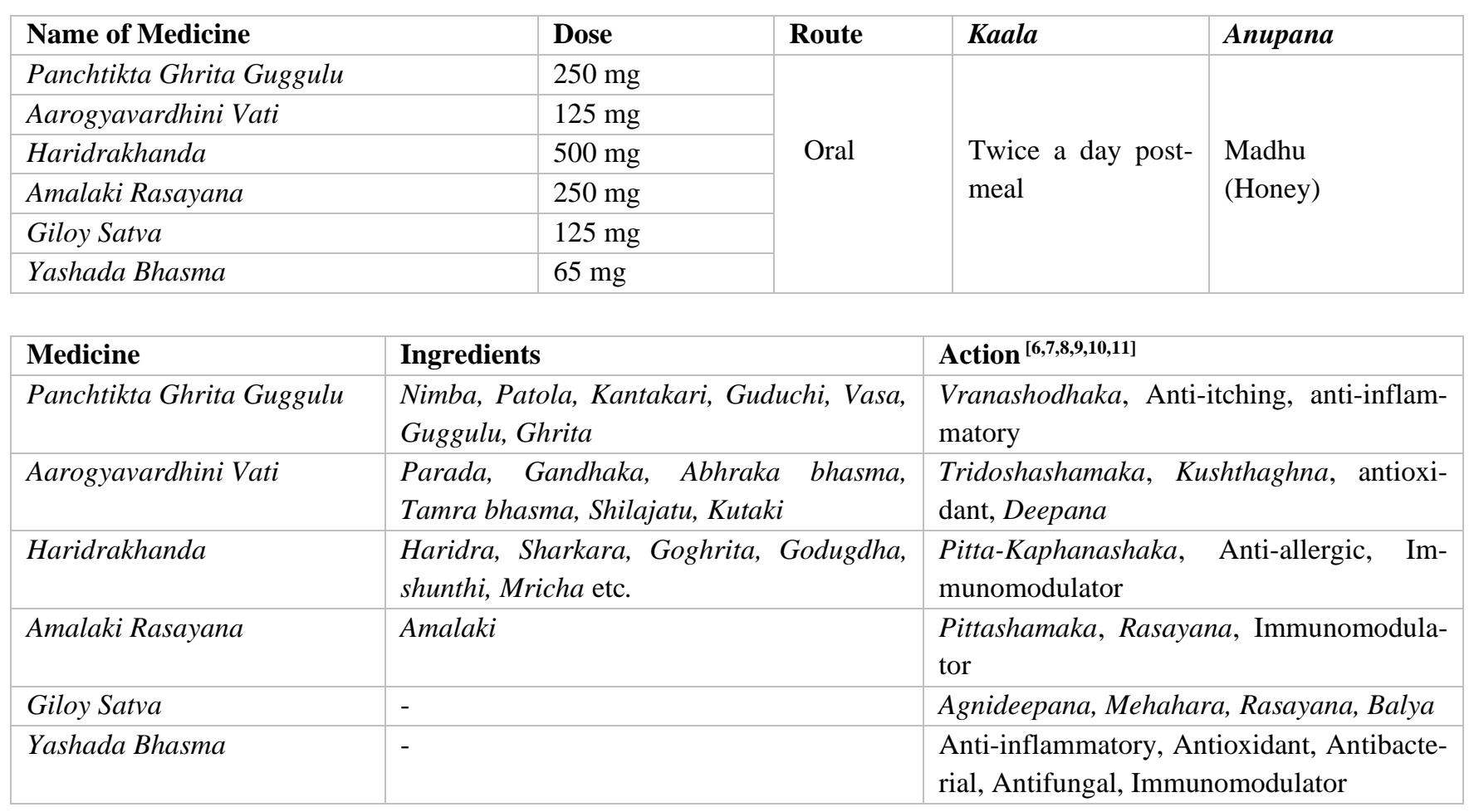

\section{For External Use:}

(a) Nasya: Anu taila 1-1 drop in each nostril at night

(b) Urtiplex lotion local application all over the affected body parts thrice a day.

\begin{tabular}{|l|l|}
\hline Contents of Urtiplex Lotion & Mode of action ${ }^{[12]}$ \\
\hline Kumari (Aloe vera) & Anti-inflammatory \\
\hline Mustard oil & Anti-inflammatory \& Antioxidant action \\
\hline Marigold oil & Anti-inflammatory \& Antioxidant action \\
\hline Menthol & The anti-pruritic and soothing effect \\
\hline kokum & Soothe skin rash \\
\hline
\end{tabular}

The above treatment was given for 45 days with regular follow-ups after every 7 days.

\section{OBSERVATIONS \& RESULTS}

Effect of treatment on the basis of assessment criteria given below:

\begin{tabular}{|l|l|l|}
\hline Criteria & Before Treatment & After Treatment \\
\hline Shotha (Swelling) & +++ & - \\
\hline Kandu (Itching) & +++ & + \\
\hline Vidaha (Burning sensation) & ++ & - \\
\hline Toda (Pricking pain) & - & - \\
\hline Jwara (Fever) & - & - \\
\hline Chhardi (Vomiting) & - & - \\
\hline
\end{tabular}

Assessment of signs and symptoms of the patient regarding Sheetapitta was done during each follow-up i.e., after every 7 days. The above table shows that there is significant relief in all signs and symptoms of
Sheetapitta (Urticaria) after about 45 days of intervention. Hence the selected management of Sheetapitta is effective. 


\section{DISCUSSION}

Sheetapitta is a Vata dominant disorder. Acharya Madhavakara has described the sign and symptoms of Sheetapitta such as Varati dashta samsthana Shotha (inflammation like an insect bite), Kandu bahula (Severe Itching), Toda bahula (excessive pricking pain), Chhardi (Vomiting), Jwara (Fever) and Vidaha (Burning sensation). Drugs in Anubhuta Yoga were mainly having Katu, Tikta, Madhura, Kashaya rasa, Guru-Snigdha guna and Sheeta virya. Hence, they act as Tridodhashamaka, Rasayana and Deepana also having Antipruritic, Antiinflammatory, Antioxidant, Immunomodulatory properties.

Urtiplex lotion which was used for local application is an anti-allergic and anti-pruritic formula that reduces inflammation relieves itching \& burning sensation and has a soothing effect on skin rashes.

\section{CONCLUSION}

Hence, it is concluded that the internal use of Polyherbal formulation along with Anu taila nasya and local application of Urtiplex lotion is highly effective in the management of Sheetapitta (Urticaria).

\section{REFERENCES}

1. PV S Prasad, Urticaria, Indian Journal of Dermatology, Venerology and Leprology, Available from www.ijdvl.com.

2. Kiran Joshi, Priya Bulbule, V.K. Kori, Role of Ahar and Dincharya in the Management of Shitpitta: A Pediatric Case Report, AYUSH: International Research Journal Teachers Association 2021;1(1):87-90.

3. Santosh Kumar Maurya, Ankit Sethi, Potential Medicinal Plants and Traditional Ayurvedic approach towards Urticaria, An Allergic skin disorder, International Journal of Pharmacy and Pharmaceutical Sciences, 2014, Vol 6, Issue 5

4. Robert M. Kliegman, Joseph W. ST Geme III, Nathan J. Blum, Robert C. Tasker, Samir S. Shah, Karen M. Wilson, Nelson Textbook of Pediatrics Vol. 1, $21^{\text {st }}$ edition, 2020 Elsevier, Chp. 173, Page no. 1222

5. Robert M. Kliegman, Joseph W. ST Geme III, Nathan J. Blum, Robert C. Tasker, Samir S. Shah, Karen M. Wilson, Nelson Textbook of Pediatrics Vol. 1, $21^{\text {st }}$ edition, 2020 Elsevier, Chp. 173, Page no. 1222
6. Smita Lokhande, Swapnil Patil, Satish Parshurami, Efficacy of Panchatikta Ghrit Guggul in the management of Mandal Kushtha with Special References to Psoriasis, IJRAP, DOI: 10.7897/2277-4343.074163, Available from www.researchgate.net.

7. Ashwini G. Gonare, Umesh N. Patil, Literary review of Aarogyavardhini vati and its effect on Kitibha Kushtha, International Journal of Research in Indian Medicine 2019, Vol. 3, Issue: $2^{\text {nd }}$, Available from www. ayurline.in

8. Makrand A. Sonare, Manoj Kumar Samantaray, Vikram, Critical Analysis of Haridra Khanda-An Ayurvedic Formulation, Journal of Ayurveda and Integrated Medical Sciences 2019, Vol 4, Issue 5

9. Shaizi Layeeq, Anup B Thakar, Clinical Efficacy of Amalaki Rasayana in the management of Pandu (Iron deficiency anemia). AYU: An International Quarterly Journal of Research in Ayurveda 2015, Vol 36, Issue 3, Available from www.ayujournal.org

10. Giloy Satva: benefits, uses ingredients, method, dosage and side-effects, May 2016, Available from www.netmeds.com

11. Seetha Chandran, Biswajyothi Patgiri, Galib R, Prasanth D, A Review through Therapeutic Attributes of Yashada bhasma, International Journal of Pharmaceutical \& Biological Archives 2016: 7(5); 6-11

12. Urtiplex anti-itch lotion, Available from www.Ayurwiki.org

\section{Source of Support: Nil Conflict of Interest: None Declared}

How to cite this URL: Verma Neeharika \& Verma Keerti: Effect Of Polyherbal Formulation In Sheetapitta (Urticaria): A Case Study. International Ayurvedic Medical Journal \{online\} 2021 \{cited December 2021\} Available from: http://www.iamj.in/posts/images/upload/3174_3178.pdf 